\title{
APLIKASI TURUNAN (DERIVATIF) \\ DALAM PERMASALAHAN ANALISIS KEUNTUNGAN MAKSIMUM
}

\author{
Oleh: Beni Asyhar \\ Jurusan Matematika UIN Maulana Malik Ibrahim Malang \\ e-mail: asyhar beni@yahoo.com
}

\begin{abstract}
Abstrak:
Penelitian ini mengkaji tentang penerapan salah satu konsep dalam kalkulus, yaitu turunan, yang merupakan hasil bagi diferensial. Turunan erat hubungannya dengan diferensial. Jika akan menentukan turunan dari suatu fungsi, maka yang perlu dilakukan adalah melakukan pendiferensialan fungsi tersebut. Fokus permasalahan dalam penelitian ini tentang aplikasi turunan dalam permasalahan analisis keuntungan maksimum dan cara membuat interpretasi dari solusi hasil turunan tersebut. Penelitian ini berlokasi di Perusahaan Istana Roti "ANITA" Kalianget-Sumenep. Pendekatan penelitiannya menggunakan pendekatan kuantitatif. Jenis datanya adalah data kuantitatif dan sumber datanya adalah buku laporan tahunan neraca keuangan. Metode pengumpulan datanya dengan observasi dan dokumentasi. Analisis data yang digunakan adalah persiapan, tabulasi, dan aplikasi turunan dalam memaksimumkan keuntungan. Berdasarkan hasil penelitian dapat disimpulkan bahwa: 1) langlah-langkah untuk mengaplikasikan turunan dalam permasalahan analisis keuntungan maksimum adalah: a) merumuskan beberapa variabel. b) menyusun model matematika. c) menyelesaikan model matematikanya. 2) Perusahaan tersebut mengalami keuntungan maksimum, karena hasil penurunan kedua adalah negatif untuk semua jenis roti.
\end{abstract}

Kata Kunci: Turunan (Derivatif), Keuntungan Maksimum

\section{Pendahuluan}

Secara umum Matematika merupakan ilmu yang mempelajari pola dari struktur, perubahan, dan ruang; secara informal. Dan dapat pula disebut sebagai ilmu tentang bilangan dan angka. Matematika merupakan alat yang dapat memperjelas dan menyederhanakan suatu keadaan atau situasi melalui abstraksi, idealisasi, atau generalisasi untuk suatu studi ataupun pemecahan masalah (Diknas, 2001:1)

Contoh sederhana dalam kehidupan sehari-hari pada saat kita mau mengatur uang belanja bagi ibu rumah tangga, uang saku anak-anak, mengatur uang kiriman bagi anak kost, dan lain-lain; secara tidak langsung semuanya 
merupakan bagian dari Matematika, yang mana hal itu membutuhkan suatu pemecahan masalah. Oleh karena itu, masalah tersebut dapat dicari solusinya dengan menggunakan ilmu Matematika, walaupun tidak dipungkiri bahwa Matematika hanya sebatas ilmu yang dipelajari untuk itu. Padahal jika ditelaah lebih mendalam, sebenarnya Matematika banyak sekali terapannya, yaitu: dalam Fisika, Kimia, Biologi, juga dalam bidang ilmu sosial, dan lain-lain.

Matematika memiliki bahasa dan aturan yang terdefinisi dengan baik, penalaran yang jelas dan sistematis, dan struktur atau keterkaitan antar konsep yang kuat. Unsur utama pekerjaan matematika adalah penalaran deduktif (penalaran yang bermula dari yang bersifat umum ke khusus) yang bekerja atas dasar asumsi (kebenaran konsistensi). Selain itu, matematika juga bekerja melalui penalaran induktif (penalaran yang bermula dari yang bersifat khusus ke umum) yang didasarkan fakta dan gejala yang muncul untuk sampai pada perkiraan tertentu. Tetapi perkiraan ini, tetap harus dibuktikan secara deduktif, dengan argumen yang konsisten.

Matematika juga merupakan suatu disiplin ilmu yang dibutuhkan dalam bidang-bidang disiplin ilmu lainnya. Perkembangan teknologi yang semakin canggih yang pada akhirnya dapat menghemat tenaga, sumber daya, dan pikiran merupakan hasil pemikiran Matematika. Akan tetapi, dengan adanya hasil pemikiran yang telah diperoleh itu tidak banyak orang yang menyadari bahwa hal itu merupakan hasil jerih payah pemikiran Matematika (Nasoetion, 1980:1).

Bagaimana mungkin dapat memahami dan menguasai hitung-menghitung dalam bidang-bidang ilmu eksak yang lain jika tidak mempunyai pengetahuan dasar tentang Matematika. Bagaimana pula dalam bidang ekonomi yang menginginkan hasil produksi tersebut baik, mempunyai laba yang maksimum, dan lain-lain? Semuanya didasarkan pada perhitungan-perhitungan Matematika. Oleh karena itu, tidak dapat dipungkiri bahwa kita dapat menghindar dari Matematika. Karena dengan Matematika kita dapat melatih jalan pikiran kita dan dengan penguasaan Matematika kita tidak akan mengalami kesulitan dalam memahami bidangbidang ilmu yang berkaitan dengan hitung-menghitung. 
3 | al-Khwarizmi, Volume II, Edisi I, Maret 2014, Hal. 1 - 14.

Kalkulus merupakan salah satu cabang dari ilmu Matematika yang mempelajari tentang hal-hal yang berhubungan dengan pencarian tingkat perubahan (pencarian arah/garis singgung pada suatu kurva) dan pencarian area yang terletak di bawah kurva (Legowo, 1984:1). Dan di dalam Kallkulus terdiri dari beberapa materi, diantaranya adalah konsep Turunan (Derivatif). Turunan (derivatif) tidak lain merupakan hasil dari suatu proses pendiferensialan atau diferensiasi dari suatu fungsi. Jadi, turunan erat sekali hubungannya dengan diferensial. Jika kita ingin menentukan turunan dari suatu fungsi, maka yang perlu dilakukan adalah melakukan pendiferensialan fungsi tersebut. Dan hasil yang diperoleh dari proses pendiferensilan itu disebut turunan (derivatif).

Diferensial membahas tentang tingkat perubahan suatu fungsi sehubungan dengan perubahan kecil dalam variabel bebas fungsi yang bersangkutan. Dengan diferensial dapat pula disidik kedudukan khusus dari fungsi yang sedang dipelajari seperti titik maksimum, titik belok dan titik minimumnya - jika ada (Dumairy, 1999:197).

Kalkulus; yang dalam hal ini turunan, merupakan suatu alat yang sangat ampuh dalam memecahkan masalah yang berhubungan dengan suatu perubahan. Perubahan di sini adalah perubahan nilai dari suatu variabel. Variabel tersebut dapat berupa variabel bebas dan variabel tidak bebas. Jika nilai variabel bebasnya berubah, maka variabel terikatnya juga akan berubah.

Berbicara masalah variabel, dalam ilmu Ekonomi kita ketahui bahwa ilmu Ekonomi pada dasarnya merupakan ilmu yang mempelajari gejala-gejala di dalam masyarakat, di mana gejala-gejala tersebut terwujud di dalam bentuk yang satu dengan yang lainnya saling mempengaruhi. Variabelvariabel tersebut banyak sekali. Oleh karena itu, untuk mempermudah di dalam perhitungan dalam Kalkulus yang berhubungan dengan Ekonomi maka diperlukan adanya penyederhanaan persoalan, yaitu dengan membatasi jumlah variabel dengan menganggap variabel-variabel lainnya tetap atau konstan (Ceteris Paribus). Atau dengan kata lain, Kalkulus dapat digunakan untuk memecahkan masalahmasalah Ekonomi jika dengan asumsi. Jika demikian, maka barulah Kalkulus (yang dalam hal ini turunan) dapat 
digunakan sebagai alat analisis di dalam memecahkan masalah-masalah Ekonomi (Legowo, 1984:2-3).

Mengingat Kalkulus (yang dalam hal ini turunan) dapat digunakan sebagai alat analisa di dalam memecahkan masalah-masalah Ekonomi, maka konsep turunan dapat kita terapkan dalam suatu perusahaan. Karena dalam suatu perusahaan sering kita menjumpai masalah-masalah atau faktor-faktor yang mempengaruhi hasil produksi, seperti: Sumber Daya Manusia (SDM), waktu, bahan, dan lain-lain. Faktor-faktor yang mempengaruhi itu merupakan suatu variabel yang sifatnya berubah-ubah, maka dengan menggunakan konsep turunan, masalah tersebut dapat kita selesaikan. Misalkan dalam suatu perusahaan, seorang manajer akan memprediksi kerugian atau keuntungan yang akan dicapai oleh perusahaan yang dikelolanya. Atau dengan kata lain, seorang manajer akan menekan sekecil mungkin biaya produksi atau memaksimumkan keuntungan (pendapatan/laba). Hal ini dapat kita selesaikan menggunakan Kalkulus (dalam hal ini adalah turunan) dengan berdasarkan pada berbagai asumsi.

Berdasarkan permasalahan di atas, maka peneliti merasa tertarik untuk mengadakan penelitian tentang aplikasi turunan (derivatif) dalam permasalahan analisis keuntungan maksimum dan interpretasi dari solusi hasil turunan (derivatif).

\section{Metode Penelitian}

\section{A. Lokasi Penelitian}

Lokasi penelitian ini adalah di Perusahaan Istana Roti "ANITA" yang berada di JI. Raya Pelabuhan No. 03 Kalianget Timur-Sumenep Telp. (0328) 661884. Perusahaan ini terletak di daerah pelabuhan antar pulau sehingga mudah dalam memperoleh bahan baku, mendapatkan tenaga kerja dan mudah dalam transportasi karena banyak dilalui angkutan umum.

\section{B. Pendekatan Penelitian}

Penelitian ini menggunakan pendekatan kuantitatif karena penelitian ini merupakan suatu bentuk penelitian yang bersifat deskriptif kuantitatif. Dikatakan deskriptif kuantitatif karena penelitian ini bertujuan untuk mendiskripsikan hasil pengolahan data yang berupa angka. 
5 | al-Khwarizmi, Volume II, Edisi I, Maret 2014, Hal. 1 - 14.

Menurut Nazir, penelitian yang menggunakan metode deskriptif bertujuan untuk membuat deskripsi, gambaran atau lukisan secara sistematis, faktual dan akurat mengenai fakta-fakta, sifat-sifat serta hubungan antar fenomena yang diselidiki (Nazir, 1988: 63).

\section{Jenis dan Sumber Data}

Arikunto menjelaskan bahwa jika penelitian yang dalam pengumpulan data dan penafsiran hasilnya tidak menggunakan angka, maka penelitian tersebut dinamakan penelitian kualitatif. Meskipun demikian, bukan berarti bahwa dalam penelitian kualitatif tidak diperbolehkan menggunakan angka. Dalam hal tertentu dapat menggunakan angka, seperti menggambarkan kondisi suatu keluarga (menyebutkan jumlah anggota keluarga, menyebutkan banyaknya biaya belanja sehari-hari, dan sebagainya), tentu saja diperbolehkan. Dalam hal ini, yang tidak diperbolehkan mempergunakan angka adalah jika dalam pengumpulan data dan penafsiran datanya menggunakan rumus-rumus statistik.

Sedangkan penelitian yang dalam pengumpulan data dan penafsiran hasilnya menggunakan angka, maka penelitian tersebut dinamakan penelitian kuantitatif (Arikunto, 2002:10). Oleh karena itu, jenis data yang digunakan adalah data kuantitatif, karena data yang diperoleh dari Perusahaan Istana Roti "ANITA" Kalianget-Sumenep adalah berupa angka.

Sumber data penelitian adalah subjek dari mana data tersebut diperoleh (Nazir, 1988:107). Jika dalam pengumpulan datanya peneliti menggunakan kuesioner, maka sumber datanya adalah responden. Jika dalam pengumpulan datanya peneliti menggunakan teknik observasi, maka sumber datanya dapat berupa benda, gerak atau proses sesuatu.

Dalam penelitian ini, yang menjadi sumber data adalah buku laporan bulanan atau tahunan, karena buku laporan bulanan atau tahunan (laporan neraca keuangan) yang ada di Perusahaan Istana Roti "ANITA" Kalianget-Sumenep merupakan satu-satunya data yang menjadi sumber data dalam penelitian ini. 


\section{Teknik Pengumpulan Data}

Pengumpulan data merupakan salah satu bagian dalam penelitian, yaitu suatu kegiatan pengadaan data untuk keperluan penelitian. Menurut Moh. Nazir, pengumpulan data adalah suatu prosedur yang sistematik dan standar untuk memperoleh data yang diperlukan (Nazir, 1988:211). Selain instrumen penelitian, pengumpulan data juga merupakan suatu hal yang tidak kalah pentingnya, terutama apabila peneliti menggunakan metode yang memiliki cukup besar celah untuk dimasuki unsur minat peneliti. Oleh karena itu, pengumpulan data harus benar-benar diperhatikan agar memperoleh data yang akurat. Berkenaan dengan hal itu, peneliti menggunakan beberapa cara atau metode dalam mengumpulkan data, yaitu: metode observasi dan dokumentasi.

\section{E. Teknik Analisis Data}

Menurut Arikunto, secara garis besar dalam melaksanakan pekerjaan analisis data meliputi 3 langkah, yaitu: 1) Persiapan, 2) Tabulasi, dan 3) Penerapan data sesuai dengan pendekatan penelitian (Arikunto, 2002:209). Oleh karena itu, langkah-langkah analisis data yang telah diperoleh dari Perusahaan Istana Roti "ANITA" KaliangetSumenep adalah sebagai berikut.

Pertama, peneliti melakukan persiapan. Dengan persiapan ini peneliti akan mendapatkan data yang akurat dan jelas, karena dalam persiapan ini peneliti mengecek kelengkapan data, artinya memeriksa kelengkapan datadata yang akan dianalisis.

Kedua, proses tabulasi data. Data tersebut adalah biaya total produksi yang dilambangkan dengan "C", harga per satu roti yang dilambangkan dengan "P" atau tingkat produksi dalam 1 tahun yang dilambangkan dengan " $x$ ", dan pendapatan (hasil penjualan roti) yang dilambangkan dengan "R".

Ketiga, aplikasi turunan (derivatif) dalam memaksimumkan keuntungan, yaitu setelah biaya total produksi, harga per satu roti atau tingkat produksi dalam 1 tahun, dan pendapatan diketahui, maka data tersebut dapat dianalisis dengan menggunakan konsep turunan (derivatif) untuk mengetahui keuntungan maksimumnya. 
7 | al-Khwarizmi, Volume II, Edisi I, Maret 2014, Hal. 1 - 14.

Agar dalam penyelesaian penentuan keuntungan maksimum tersebut tidak mengalami kesulitan, maka peneliti menyusun langkah-langkah sebagai berikut:

1. Menentukan fungsi biaya, fungsi harga (permintaan), dan fungsi penerimaannya.

2. Kemudian tentukan fungsi keuntungannya, yaitu: $\pi=R-C$

3. Menentukan turunan pertamanya, yaitu: $\pi^{\prime}$

4. Turunan pertama fungsi keuntungan tersebut sama dengankan nol, yaitu:

$\pi^{\prime}=0$, di mana dari hasil tersebut akan diperoleh suatu titik kritis atau titik ekstrim yang dalam hal ini akan sangat berguna untuk menentukan keuntungan/kerugian maksimum. Jika hanya menggunakan hasil turunan pertama untuk menentukan keuntungan/kerugian maksimum, maka akan mengalami kesulitan. Oleh karena itu, dengan melanjutkan langkah 5, maka dengan cepat dan mudah titik kritis atau titik ekstrim tersebut dapat dipastikan apakah titik tersebut merupakan titik maksimum atau titik minimum.

5. Lanjutkan untuk menentukan turunan kedua dari fungsi keuntungan, yaitu: $\pi^{\prime \prime}$ Kemudian sama dengankan nol, yaitu: $\pi^{\prime \prime}=0$, sehingga diperoleh aturan sebagai berikut:

a. Jika titik tersebut disubstitusikan ke $\pi^{\prime \prime}$ dan hasilnya negatif, maka suatu titik tersebut menunjukkan bahwa kurvanya pada titik tersebut terbuka ke bawah (concave downward) dan titik tersebut adalah titik maksimum (Keuntungan Maksimum).

b. Jika titik tersebut disubstitusikan ke $\pi^{\prime \prime}$ dan hasilnya positif, maka suatu titik tersebut menunjukkan bahwa kurvanya pada titik tersebut terbuka ke atas (concave up ward) dan titik tersebut adalah titik minimum (Kerugian Maksimum).

\section{Hasil Penelitian}

Berdasarkan hasil pengumpulan data penelitian, peneliti mendapatkan beberapa data yang diperlukan untuk dijadikan bahan penelitian ini. Data yang peneliti peroleh adalah berupa angka-angka, yaitu: data tentang biaya produksi, jumlah produksi, dan harga dari hasil produksi 
Perusahaan Istana Roti "ANITA" Kalianget-Sumenep. Untuk itu, peneliti menulisnya dalam bentuk tabel sebagai berikut.

Tabel 1. Biaya Tetap yang Dikeluarkan Oleh Perusahaan Istana Roti "ANITA" Kalianget-Sumenep

\begin{tabular}{|c|l|l|}
\hline No & \multicolumn{1}{|c|}{ Uraian } & \multicolumn{2}{|c|}{ Jumlah (Rupiah) } \\
\hline 1 & Pajak (dalam 1 tahun) & Rp. 5.099.000,- \\
2 & Pemeliharaan alat & Rp. 1.200.000,- \\
3 & Iklan & Rp. 600.000,- \\
4 & Gaji bulanan karyawan tetap & Rp. 20.400.000,- \\
5 & Beban biaya listrik dan & Rp. 764.800,- \\
& telepon & \\
\hline \multicolumn{1}{|c|}{ T O T A L } & Rp. 28.063.800,-- \\
\hline
\end{tabular}

Tabel 2. Biaya Variabel yang Dikeluarkan Oleh Perusahaan Istana Roti "ANITA" Kalianget-Sumenep

\begin{tabular}{|c|l|l|lc|}
\hline No & \multicolumn{1}{|c|}{ Uraian } & $\begin{array}{c}\text { Biaya Variabel } \\
\text { Total (VC) }\end{array}$ & \multicolumn{2}{|c|}{$\begin{array}{c}\text { Biaya Variabel } \\
\text { Rata-rata } \\
\text { (AVC) }\end{array}$} \\
\hline 1 & Roti Tawar & Rp. $10.155 .450,-$ & Rp. & $1.499,-$ \\
2 & Roti Tawar Susu & Rp. $10.105 .350,-$ & Rp. & $1.182,-$ \\
3 & Roti Manis & Rp. $9.099 .400,-$ & Rp. & $1.344,-$ \\
4 & Roti Isi Keju & Rp. $10.975 .600,-$ & Rp. & $1.492,-$ \\
5 & Roti Panca Rasa & Rp. $10.183 .750,-$ & Rp. & $1.348,-$ \\
6 & Roti Coklat & Rp. $9.053 .000,-$ & Rp. & $1.295,-$ \\
7 & Roti Pisang Coklat & Rp. $10.035 .300,-$ & Rp. & $715,-$ \\
8 & Roti Isi Sosis & Rp. $10.525 .650,-$ & Rp. & $750,-$ \\
9 & Roti Isi Kacang & Rp. $9.931 .250,-$ & Rp. & $392,-$ \\
10 & Roti Selai & $R p .99 .370 .450,-$ & Rp. & $377,-$ \\
\hline
\end{tabular}

Tabel 3. Hasil Produksi dan Harga Hasil Produksi Roti Perusahaan Istana Roti "ANITA" Kalianget-Sumenep Tahun 2004

\begin{tabular}{|c|l|r|cc|}
\hline No & \multicolumn{1}{|c|}{ Uraian } & Volume & \multicolumn{2}{|c|}{ Harga/roti } \\
\hline 1 & Roti Tawar & 6.775 roti & Rp. & $6.250,-$ \\
2 & Roti Tawar Susu & 8.550 roti & Rp. & $5.750,-$ \\
3 & Roti Manis & 6.770 roti & Rp. & $6.250,-$ \\
4 & Roti Isi Keju & 7.355 roti & Rp. & $6.250,-$ \\
5 & Roti Panca Rasa & 7.555 roti & Rp. & $6.750,-$ \\
6 & Roti Coklat & 6.990 roti & Rp. & $6.250,-$ \\
7 & Roti Pisang Coklat & 14.045 roti & Rp. & $3.250,-$ \\
8 & Roti Isi Sosis & 14.025 roti & Rp. & $3.250,-$ \\
9 & Roti Isi Kacang & 25.350 roti & Rp. & $1.750,-$ \\
10 & Roti Selai & 24.880 roti & Rp. & $1.750,-$ \\
\hline
\end{tabular}


9 | al-Khwarizmi, Volume II, Edisi I, Maret 2014, Hal. 1 - 14.

Tabel 4. Hasil Produksi dan Harga Hasil Produksi Roti Perusahaan Istana Roti "ANITA" Kalianget-Sumenep Tahun 2003

\begin{tabular}{|c|l|r|c|}
\hline No & \multicolumn{1}{|c|}{ Uraian } & \multicolumn{1}{c|}{ Volume } & Harga/roti \\
\hline 1 & Roti Tawar & 6.000 roti & Rp. $6.500,-$ \\
2 & Roti Tawar Susu & 7.750 roti & Rp. $6.000,-$ \\
3 & Roti Manis & 5.500 roti & Rp. $6.500,-$ \\
4 & Roti Isi Keju & 6.100 roti & Rp. $6.500,-$ \\
5 & Roti Panca Rasa & 6.200 roti & Rp. $7.000,-$ \\
6 & Roti Coklat & 5.335 roti & Rp. $6.500,-$ \\
7 & Roti Pisang Coklat & 13.050 roti & Rp. $3.500,-$ \\
8 & Roti Isi Sosis & 13.075 roti & Rp. $3.500,-$ \\
9 & Roti Isi Kacang & 24.300 roti & Rp. $2.000,-$ \\
10 & Roti Selai & 23.700 roti & Rp. $2.000,-$ \\
\hline
\end{tabular}

Berdasarkan Tabel 1 dan 2 dapat diperoleh fungsi biaya (C) untuk masing-masing jenis roti. Sedangkan berdasarkan Tabel 3 dan 4 dapat diperoleh fungsi harga (permintaan) $(P)$ untuk masing-masing jenis roti. Jika fungsi harga (permintaan) $(P)$ dikalikan dengan jumlah barang yang dihasilkan $(Q)$, maka akan diperoleh fungsi penerimaan $(R)$. Selanjutnya, jika fungsi penerimaan $(R)$ dikurangi fungsi biaya $(C)$, maka akan diperoleh fungsi keuntungan $(\pi)$. Kemudian, fungsi keuntungan ini dianalisis untuk memperoleh keuntungan yang maksimum dengan menggunakan konsep turunan (derivatif).

\section{Pembahasan}

Sebelum menganalisis keuntungan maksimum, berikut ini beberapa model matematika (fungsi) dari variabelveriabel data penelitian yang dijelaskan pada tabel 3.1, 3.2, 3.3, dan 3.4. Model matematika tersebut berupa fungsi biaya $(C)$, fungsi harga (permintaan) $(P)$, fungsi penerimaan $(R)$, dan fungsi keuntungan $(\pi)$ untuk masing-masing jenis roti yang diproduksi.

1. Roti Tawar

$$
\begin{aligned}
& C=28.063 .800+1.499 Q, P=-0.32 Q+8.420, \\
& R=-0.32 Q^{2}+8.420 Q, \\
& \pi=-0.32 Q^{2}+6.921 Q-28.063 .800
\end{aligned}
$$

2. Roti Tawar Susu

$$
C=28.063 .800+1.182 Q, P=-0.31 Q+8.403 \text {, }
$$




$$
\begin{aligned}
& R=-0.31 Q^{2}+8.403 Q, \\
& \pi=-0.31 Q^{2}+7.221 Q-28.063 .800
\end{aligned}
$$

dan

3. Roti Manis

$$
\begin{aligned}
& C=28.063 .800+1.344 Q, P=-0.20 Q+6.600, \\
& R=-0.20 Q^{2}+6.600 Q, \\
& \pi=-0.20 Q^{2}+5.256 Q-28.063 .800
\end{aligned}
$$

dan

4. Roti Isi Keju

$$
\begin{aligned}
& C=28.063 .800+1.492 Q, P=-0.20 Q+7.720, \\
& R=-0.20 Q^{2}+7.720 Q, \\
& \pi=-0.20 Q^{2}+6.228 Q-28.063 .800
\end{aligned}
$$

dan

5. Roti Panca Rasa

$$
\begin{aligned}
& C=28.063 .800+1.348 Q, P=-0.18 Q+8.116, \\
& R=-0.18 Q^{2}+8.116 Q, \\
& \pi=-0.18 Q^{2}+6.768 Q-28.063 .800
\end{aligned}
$$

dan

6. Roti Coklat

$$
\begin{aligned}
& C=28.063 .800+1.295 Q, P=-0.15 Q+7.300, \\
& R=-0.15 Q^{2}+7.300 Q, \\
& \pi=-0.15 Q^{2}+6.005 Q-28.063 .800
\end{aligned}
$$

dan

7. Roti Pisang Coklat

$$
\begin{aligned}
& C=28.063 .800+715 Q, P=-0.25 Q+6.763, \\
& R=-0.25 Q^{2}+6.763 Q, \\
& \pi=-0.25 Q^{2}+6.048 Q-28.063 .800
\end{aligned}
$$

dan

8. Roti Isi Sosis

$$
\begin{aligned}
& C=28.063 .800+750 Q, P=-0.26 Q+6.900, \\
& R=-0.26 Q^{2}+6.900 Q, \\
& \pi=-0.26 Q^{2}+6.150 Q-28.063 .800
\end{aligned}
$$

dan

9. Roti Isi Kacang

$$
\begin{aligned}
& C=28.063 .800+392 Q, \quad P=-0.24 Q+7.832, \\
& R=-0.24 Q^{2}+7.832 Q, \\
& \pi=-0.24 Q^{2}+7.440 Q-28.063 .800
\end{aligned}
$$


11 | al-Khwarizmi, Volume II, Edisi I, Maret 2014, Hal. 1 - 14.

10. Roti Selai

$$
\begin{aligned}
& C=28.063 .800+377 Q, P=-0.21 Q+6.977, \\
& R=-0.21 Q^{2}+6.977 Q, \\
& \pi=-0.21 Q^{2}+6.600 Q-28.063 .800
\end{aligned}
$$

dan

Berdasarkan fungsi keuntungan $(\pi)$ pada masingmasing jenis roti, jika dicari turunan pertamanya, maka akan diperoleh suatu titik kritis atau titik ekstrim, kemudian titik ekstrim tersebut diuji menggunakan turunan kedua untuk mengetahui titik maksimum atau minimum. Jika hasil uji turunan kedua negatif $\left(\pi^{\prime \prime}<0\right)$, maka dapat disimpulkan bahwa titik tersebut merupakan titik maksimum.

Jika hasil uji turunan kedua negatif $\left(\pi^{\prime \prime}<0\right)$, maka menunjukkan bahwa Perusahaan Istana Roti "ANITA" Kalianget-Sumenep akan memperoleh keuntungan maksimum pada tingkat produksi tertentu dalam 1 tahun. Adapun selesaian fungsi keuntungan pada masing-masing jenis roti adalah sebagai berikut.

1. Roti Tawar

$$
\begin{aligned}
& \pi^{\prime}=-0.64 Q+6.921 \Rightarrow Q=10.814 \\
& \pi^{\prime \prime}=-0.64<0
\end{aligned}
$$

2. Roti Tawar Susu

$$
\begin{aligned}
& \pi^{\prime}=-0.62 Q+7.221 \Rightarrow Q=11.647 \\
& \pi^{\prime \prime}=-0.62<0
\end{aligned}
$$

3. Roti Manis

$$
\begin{aligned}
& \pi^{\prime}=-0.40 Q+5.256 \Rightarrow Q=13.140 \\
& \pi^{\prime \prime}=-0.40<0
\end{aligned}
$$

4. Roti Isi Keju

$$
\begin{aligned}
& \pi^{\prime}=-0.40 Q+6.228 \Rightarrow Q=15.570 \\
& \pi^{\prime \prime}=-0.40<0
\end{aligned}
$$

5. Roti Panca Rasa

$$
\begin{aligned}
& \pi^{\prime}=-0.36 Q+6.768 \Rightarrow Q=18.800 \\
& \pi^{\prime \prime}=-0.36<0
\end{aligned}
$$

6. Roti Coklat 


$$
\begin{aligned}
& \pi^{\prime}=-0.30 Q+6.005 \Rightarrow Q=20.017 \\
& \pi^{\prime \prime}=-0.30<0
\end{aligned}
$$

7. Roti Pisang Coklat

$$
\begin{aligned}
& \pi^{\prime}=-0.50 Q+6.048 \Rightarrow Q=12.096 \\
& \pi^{\prime \prime}=-0.50<0
\end{aligned}
$$

8. Roti Isi Sosis

$$
\begin{aligned}
& \pi^{\prime}=-0.52 Q+6.150 \Rightarrow Q=11.827 \\
& \pi^{\prime \prime}=-0.52<0
\end{aligned}
$$

9. Roti Isi Kacang

$$
\begin{aligned}
& \pi^{\prime}=-0.48 Q+7.440 \Rightarrow Q=15.500 \\
& \pi^{\prime \prime}=-0.48<0
\end{aligned}
$$

10. Roti Selai

$$
\begin{aligned}
& \pi^{\prime}=-0.42 Q+6.600 \Rightarrow Q=15.714 \\
& \pi^{\prime \prime}=-0.42<0
\end{aligned}
$$

Berdasarkan hasil selesaian fungsi keuntungan $(\pi)$ pada masing-masing jenis roti dapat disimpulkan bahwa perusahaan tersebut mengalami keuntungan maksimum, karena hasil turunan kedua negatif $\left(\pi^{\prime \prime}<0\right)$ untuk semua jenis roti. Untuk Roti Tawar, perusahaan akan memperoleh keuntungan maksimum pada saat memproduksi roti sebanyak 10.814, Roti Tawar Susu sebanyak 11.647, Roti Manis sebanyak 13.140, Roti Isi Keju sebanyak 15.570, Roti Panca Rasa sebanyak 18.800, Roti Coklat sebanyak 20.017, Roti Pisang Coklat sebanyak 12.096, Roti Isi Sosis sebanyak 11.827, Roti Isi Kacang sebanyak 15.500, dan Roti Selai sebanyak 15.714 dalam 1 tahun. Sehingga, Perusahaan Istana Roti "ANITA" Kalianget-Sumenep akan memperoleh keuntungan maksimum pada tingkat produksi 145.125 roti dalam 1 tahun. 
13 | al-Khwarizmi, Volume II, Edisi I, Maret 2014, Hal. 1 - 14.

\section{Kesimpulan Dan Saran \\ A. Kesimpulan}

Dari hasil penelitian dan pembahasan, maka dapat disimpulkan bahwa:

1. Langkah-langkah untuk mengaplikasikan turunan (derivatif) dalam Permasalahan Analisis Keuntungan Maksimum adalah:

a. Berdasarkan data yang diperoleh, dirumuskan beberapa variabel, yaitu: biaya total dan biaya variabel perusahaan dalam memproduksi roti, biaya tetap perusahaan, jumlah roti yang dihasilkan, harga roti per biji, penerimaan total, dan keuntungan.

b. Menyusun model matematika (fungsi) dari variabelveriabel yang diperoleh.

c. Menyelesaikan model matematika.

2. Perusahaan Istana Roti "ANITA" Kalianget-Sumenep mengalami keuntungan maksimum, karena hasil turunan kedua negatif $\left(\pi^{\prime \prime}<0\right)$ untuk semua jenis roti. Keuntungan maksimum akan diperoleh pada saat memproduksi 145.125 roti dalam 1 tahun.

\section{B. Saran}

Saran yang bisa diberikan berkaitan dengan penelitian ini adalah:

1. Hendaknya apa yang telah dilakukan oleh Perusahaan Istana Roti "ANITA" Kalianget-Sumenep dijadikan sebagai usaha yang masih perlu ditingkatkan secara kontinyu.

2. Mengingat konsep turunan (derivatif) bukanlah satusatunya konsep atau alat untuk menganalisis keuntungan maksimum, maka disarankan kepada pihak yang berminat, untuk mencari cara atau metode lain dalam memaksimumkan keuntungan.

\section{DAFTAR PUSTAKA}

Arikunto, Suharsimi. 2002. Prosedur Penelitian: Suatu Pendekatan Praktek. Jakarta: PT. Rineka Cipta.

Badan Penelitian dan Pengembangan Kurikulum. 2001. Kurikulum Berbasis Kompetensi: Mata Pelajaran Matematika. Jakarta: Departemen Pendidikan Nasional. 
Aplikasi Turunan (Derivativ) ...| 14

Dumairy. 1999. Matematika Terapan untuk Bisnis dan Ekonomi. Yogyakarta: BPFE-Yogyakarta.

Legowo. 1984. Dasar-dasar Kalkulus dan Penerapannya dalam Ekonomi. Jakarta: Lembaga Penerbitan Fakultas Ekonomi Universitas Indonesia.

Nasoetion, Andi Hakim. 1980. Landasan Matematika. Jakarta: Bhratara Karya Aksara.

Nazir, M. 1988. Metode Penelitian. Jakarta: Ghalia Indonesia. 